Rok XVI (2021) | 2 (32) | S. 319-330

https://doi.org/10.12797/LV.16.2021.32.24

Alicja Stankiewicz 0

Uniwersytet Wrocławski, Wrocław

alicja.stankiewicz@uwr.edu.pl

\title{
KONCEPTUALIZACJA NADZIEI W METAFORACH POJĘCIOWYCH W WYPOWIEDZIACH PACJENTÓW CHORYCH NA NOWOTWÓR ZłOŚLIWY NA TLE WYPOWIEDZI OSÓB ZDROWYCH
}

\begin{abstract}
Słowa klucze: nadzieja, konceptualizacja, metafora pojęciowa, nowotwór złośliwy Keywords: hope, conceptualization, conceptual metaphor, cancer
\end{abstract}

\section{Wprowadzenie}

Celem artykułu jest sprawdzenie, w jaki sposób mówią o nadziei ludzie chorzy na nowotwór złośliwy oraz jak obraz nadziei wyłaniający się z ich wypowiedzi sytuuje się na tle narracji osób zdrowych, a zwłaszcza za pomocą jakich metafor pojęciowych konceptualizowane jest to uczucie. Analizie poddano konstrukcje językowe należące do dwóch grup tekstów: badawczej i kontrolnej, które obejmują materiał zaczerpnięty odpowiednio z blogów osób zmagających się z chorobą nowotworową oraz z pamiętników o tematyce lifestyle’owej.

Opisu semantyki wybranych nazw emocji jako pierwsza dokonała Anna Wierzbicka (1971), która pracując nad teorią naturalnego metajęzyka semantycznego, dowodziła, że nie istnieją uniwersalne pojęcia emocji. W ciągu kilkudziesięciu lat badań nad językiem emocji opracowała ona odpowiednie narzędzia do opisu uczuć, między innymi skrypt kulturowy (Wierzbicka 1999). W latach 9o. XX w. w obszarze językoznawczych badań nad emocjami zaczęto korzystać z podejścia kognitywnego, które cieszy się do dzisiaj niesłabnącym zainteresowaniem. Powstały wówczas obszerne opracowania Iwony Nowakowskiej-Kempnej dotyczące konceptualizacji 
uczuć (1995, 2000). Następnie pojawiły się prace opisujące językowo-kulturowy obraz poszczególnych emocji: gniewu (np. Mikołajczuk 1999; Duszak, Pawlak 2003), strachu (np. Tomczak 1994; Karaś 2003), wstydu (np. Jędrzejko 200o) czy radości (np. Mikołajczuk 2009; Popowicz 2018).

\section{Nadzieja w ujęciu lingwistycznym}

Najistotniejsze dla prowadzonych analiz wydają się badania nad radością, w ramach których badacze zaledwie wspominają o nadziei. Emocja ta znajduje się na peryferiach leksykalnego pola uczuć z rodziny radości, a najistotniejszą cechą odróżniającą nadzieję od innych emocji jest ukierunkowanie na przyszłość i dominująca rola elementu poznawczego (a nie emocjonalnego) (Mikołajczuk 2009, 2013). Do kategorii nadziei należą zatem uczucia spowodowane myślą o czymś dobrym, co może wydarzyć się w przyszłości (Popowicz 2018: 119).

Trudno odnaleźć na gruncie polskim obszerniejsze badania poświęcone wyłącznie semantyce nadziei. Jako przykład mogą posłużyć prace mieszczące się w nurcie językoznawstwa strukturalnego: artykuły Adama Bednarka O nadziei. Próba definicji semantycznej (1989) czy Piotra Sobotki Norwidowska koncepcja nadziei (2010). A. Bednarek analizuje 160 cytatów zawierających słowo nadzieja zaczerpniętych $\mathrm{z}$ literatury pięknej i dowodzi, że nadzieja jest ściśle powiązana $\mathrm{z}$ wiarą $\mathrm{w}$ określony porządek świata, który wynika z przyjętego systemu wartości. W konsekwencji badacz proponuje następującą eksplikację tego pojęcia:

$\mathrm{X}$ ma nadzieję ' $\mathrm{X}$ wierzy, że jeżeli stanie się coś, czego X nie chciałby, aby się stało, to stanie się coś, co będzie dla $\mathrm{X}$ dobre i o czym myśląc, $\mathrm{X}$ nie będzie mógł nie myśleć o tym, co się stało, bo X wierzy, że świat jest taki, że tak być powinno' (Bednarek 1989: 348-349).

Wydaje się, że wiara zastępuje w definicji Bednarka myśl, o której pisze Joanna Popowicz (2018). Co istotne, w eksplikacjach obojga badaczy nadzieja opisana zostaje jako uczucie ukierunkowane na przyszłość. P. Sobotka również analizuje materiał pozyskany z literatury pięknej i poddaje refleksji zagadnienia dotyczące przeżywania i sposobu wyrażania nadziei w twórczości Cypriana Kamila Norwida oraz porusza problem związku zachodzącego między specyfiką emocji zawartą w dziełach tego poety a znaczeniem nadziei w polszczyźnie ogólnej. O uczuciu tym wspomina się także na gruncie aksjolingwistyki. Nadzieja ujęta została na liście stu haseł proponowanych do opisu w ramach polskiego słownika aksjologicznego, wśród nazw wartościowanych postaw ogólnoludzkich (Bartmiński 1989: 302)1․

1 Prace nad słownikiem rozwinęły się w projekt badawczy „Językowo-kulturowy obraz świata Słowian i ich sąsiadów na tle porównawczym” (w skrócie EUROJOS) prowadzony pod kierunkiem Jerzego Bartmińskiego. 


\section{Psychologiczne koncepcje nadziei}

W przeciwieństwie do skromnych opisów językoznawczych znacznie obszerniejszych definicji nadziei dostarcza literatura psychologiczna. O ile w językoznawstwie kognitywnym panuje zgoda co do tego, że nadzieję należy uznać za emocję, o tyle na gruncie psychologii odnaleźć można wiele ujęć. Barbara Gawda (2018) dzieli definicje na trzy grupy: uznające nadzieję za konstrukt motywacyjno-poznawczy, dyspozycję osobowościową oraz emocję. Do pierwszej grupy można zaliczyć na przykład koncepcję Józefa Kozieleckiego (2006). W jego ujęciu nadzieja to wielowymiarowa struktura poznawcza obejmująca emocje, myśli o czasie przyszłym, sądy afiliatywne, motywy i czynniki sprawcze. To wszystko tworzy według Kozieleckiego całość psychiczną, w której dominującą rolę odgrywa poznanie. Badacz wysuwa tezę o istnieniu czterech rodzajów nadziei: pasywnej partykularnej, pasywnej generalnej, aktywnej partykularnej oraz aktywnej generalnej (ibid.: 38), a także wyróżnia pięć postaci nadziei. Pierwszą jest falowanie nadziei, kiedy jej intensywność zmienia się w czasie. Mininadzieja odnosi się do długiego okresu, gdy prawdopodobieństwo pomyślnego zakończenia pewnego przedsięwzięcia jest znikome; przykład mogą stanowić pacjenci w krytycznym stanie, wierzący w pozytywny przebieg operacji obarczonej wysokim ryzykiem. Nadzieja skoncentrowana na innych dotyczy sytuacji, kiedy osiągniecie pożądanego dobra ma posłużyć innym, zwykle bliskim osobom. O nadziei zapożyczonej można mówić wtedy, kiedy jej źródłem staje się pewna osoba, na przykład lekarz w relacji z pacjentem. Nadzieja fasadowa jest zaś nadzieją na pokaz - przejętą pod wpływem norm narzucanych przez społeczeństwo (ibid.: 112-115).

Wśród twórców poznawczych definicji nadziei można wymienić Charlesa R. Snydera (2002), ujmującego nadzieję jako konstrukt motywacyjny, na który składają się wewnętrzna i zewnętrzna siła ukierunkowana na cel oraz drogi prowadzące do tego celu. O nadziei jako dyspozycji osobowościowej pisze na przykład Erik Erikson (1985), postrzegając to zjawisko jako pewną siłę, dominującą u ludzi szczególnie w okresie niemowlęctwa, i tym samym twierdząc, że to podstawowy czynnik rozwoju ego (Erikson 2002: 70-75). Nadzieję jako emocję definiuje między innymi Richard S. Lazarus (1999), według którego „mieć nadzieję” to znaczy wierzyć w coś pozytywnego, a więc tęsknić za tym, co nie odnosi się aktualnie do naszego życia, ale wciąż może się urzeczywistnić. W ujęciu Lazarusa nadzieja jest odpowiedzią na zaistniałą niekorzystną okoliczność i powinna być ważnym zasobem psychologicznym (ibid.: 653-654). 


\section{Materiał}

$\mathrm{Na}$ materiał badawczy składają się dane językowe pozyskane $\mathrm{z}$ blogów, podzielone na dwie grupy: badawczą oraz kontrolną. Grupę badawczą stanowią wypowiedzi osób chorych na nowotwór złośliwy - raka, mięsaka, chłoniaka lub białaczkę (Kruś, Skrzypek-Fakhoury 2007) w różnym stadium zaawansowania, u których najczęstszym tematem wpisów są zmagania z procesem nowotworowym. Grupę kontrolną tworzą dane językowe pozyskane $z$ blogów ludzi zdrowych - są to blogi o tematyce lifestyle'owej, w których autorzy nie przekazują treści związanych z chorobą. Wyekscerpowano po 42 blogi, zachowując w obu grupach zależności ilościowe pod względem płci - 35 pamiętników pisanych przez kobiety i 7 przez mężczyzn. Dysproporcja ta zdaje się sugerować, że u kobiet istnieje większa gotowość do publicznego mówienia o emocjach oraz snucia refleksji². Blogi wyszukano za pomocą wyszukiwarki Google, wpisując dla grupy podstawowej hasło: „site:blogspot.com nazwa nowotworu”, a dla grupy kontrolnej „site:blogspot.com blog kobiety / blog mężczyzny". W grupie podstawowej wyekscerpowano 646 kolokacji słowa nadzieja, z czego kolokacje metaforyczne stanowią $17,49 \%$, w grupie kontrolnej odnaleziono zaś 552 kolokacje, wśród nich 11,41\% uznano za metaforyczne.

\section{Metodologia}

Zręby kognitywnej teorii metafory stanowi koncepcja George’a Lakoffa i Marka Johnsona (1980/2010), która jest nieustannie rozwijana. Zoltan Kövecses, korzystając $\mathrm{z}$ ich dorobku, definiuje metaforę jako zestaw odwzorowań między domeną źródłową a docelową. Podstawą zależności między dwoma pojęciami, z których jedno podlega rozumieniu, a drugie służy do jego objaśnienia, jest podobieństwo albo ucieleśnienie (Kövecses 2002). Według badacza metafory (obok wyrażeń literalnych) należą do zasobu języka, dzięki któremu ludzie są w stanie opisywać emocje, a konkretniej - różne ich aspekty, na przykład intensywność czy przyczynę (Kövecses 200o: 3-6). Wyrażenia metaforyczne stanowią więc unikalny sposób wyrażania uczuć: dają możliwości konceptualizacji pewnych ich aspektów, jakich nie gwarantują inne słowa, a ponadto pozwalają na kreowanie rzeczywistości społecznej, kulturowej czy psychologicznej (ibid.: 16-17). Kövecses w nowszych pracach (por. 2017) zwraca szczególną uwagę na rolę kontekstu w tworzeniu metafor w dyskursie. Wymienia cztery rodzaje procesów kognitywnych, które są konieczne do utworzenia odwzorowania metaforycznego. Jako pierwszy z nich wskazuje operacje poznawcze (interpretujące), z których zbioru nadawca wybiera metaforę służącą do tworzenia

2 O zależności tej wspominają często psycholodzy. Znajduje ona też odbicie w niechęci do korzystania z pomocy psychologicznej czy psychoterapeutycznej przez mężczyzn (Klatkiewicz 2010: 42). 
sensu. Drugim są według badacza czynniki kontekstowe, od których zależy użycie metafory i które składają się na kolejny proces kognitywny, a mianowicie na torowanie kontekstowe. Ostatnim procesem poznawczym są ścieżki konceptualne, dzięki którym metafora zyskuje znaczenie zgodne z intencją konceptualizatora.

\section{Analiza}

Analizie poddano dane językowe ${ }^{3}$, w których uczucie nadziei jest konceptualizowane za pomocą metafor pojęciowych - zostaną one przedstawione i omówione zgodnie z częstością występowania (każdy typ zilustrowano wybranymi przykładami). Zarówno w grupie badawczej, jak i kontrolnej najczęściej pojawia się metafora NADZIEJA TO RZECZ CENNA (29 i 26 poświadczeń). Kolejne domeny źródłowe wykorzystywane w grupie badawczej to: ISTOTA ŻYWA (18), CIECZ (15), OGIEŃ (11), PRZEDMIOT KRUCHY (4), ZIARNO (2), MATKA (2). W grupie kontrolnej nadzieja jawi się zaś jako CIECZ (8), OGIEŃ (6), ISTOTA ŻYWA (5), MATKA (2) oraZ ZBIORNIK WODNY (2).

\section{Nadzieja to rzecz cenna}

U podstaw metafory NADZIEJA TO RZECZ CENNA leży schemat wyobrażeniowy PRZEDMIOTU (Johnson 1987). Ludzie najczęściej obawiają się, że ktoś może im nadzieję odebrać albo sami mogą ją stracić lub zostać jej pozbawieni; analogicznie nadzieję można też komuś podarować, często ludzie także szukają tego doświadczenia.

Konstrukcje, w których nadzieja łączy się z czasownikiem tracić, charakteryzują się dużą sprawczością konceptualizatora, występującego w roli agensa. W przykładzie (1) pacjent nie chce dopuścić do utraty nadziei, szuka racjonalnych argumentów przemawiających za tym, aby ją zachować. Dwukrotne przeczenie podkreśla kontrfaktyczność niepożądanego stanu utraty cennej nadziei:

(1) Nie. Nie tracę nadziei. Brazylijska baza dawców jeszcze nie cała przekopana. Kilku kawalerów nadal nie sprawdzono...

Agensem może być nie tylko pacjent, ale też lekarz, który jest w stanie swoimi poczynaniami odebrać pacjentowi nadzieję. W wypowiedziach takich odszukać można dobre przykłady nadziei zapożyczonej opisywanej przez J. Kozieleckiego (2006). W poniższym przykładzie źródłem tego doświadczenia stała się lekarka - jej słowa oraz spojrzenie odebrały nadzieję chorej.

3 W przywołanych cytatach zachowano oryginalną pisownię. 
(2) Co ta kobieta do mnie mówi???!!! Walczę, leczę się, chodzę, egzystuje a ona odbiera mi całą nadzieje. Sama sobie zaprzeczała patrząc na mnie i mówiąc, „to niesamowite jak Pani wygląda, jak Pani się czuje na to na co Pani choruje”.

Nadzieja może być konceptualizowana jako obiekt poszukiwań, który zostaje nie tyle odnaleziony przez konceptualizatora, ile podarowany mu:

(3) Na grupie FB „Syrenki” tyle Was szuka pociechy, wsparcia, otuchy, dobrego słowa, nadziei. Szukacie, ja też szukałam... Dostałam i chcę Wam o tym, teraz napisać.

W przykładzie (4) nadzieja jawi się jako rzecz, której zaczyna brakować. Zamiast tej emocji pojawia się strach. Zdaniem J. Kozieleckiego (2006: 56) lęk i strach oraz nadzieja to dwie nieodłączne siły, które współwystępują w życiu człowieka.

(4) W moim przypadku ten strach jest o wiele większy niż kiedy dowiedziałam się o raku piersi. Teraz brakuje elementu niedowierzania, który jednak troszkę mnie dystansował. Brakuje nadziei, no bo jeżeli jednak wznowa to rokowania już gorsze.

$\mathrm{W}$ wypowiedziach z grupy badawczej przeważają konstrukcje, w których doświadczający nie jest agensem, natomiast osoby zdrowe, mówiąc o utracie nadziei, wykazują się większą sprawczością.

(5) W życiu mamy swoje zasady czy zdolności, trzymamy się ich, gdy widzimy że są dobre dla nas, dążymy do realizacji kolejnych planów. Ale co w przypadku, gdy inni na tych naszych przekonaniach tracą? Tracą nie tylko wiarę czy nadzieję, ale i bliskich.

W przykładzie (5) nadzieja zestawiona zostaje $\mathrm{z}$ wiarą. Przypuszczalnie jest to fragment dobrze utrwalonego w polszczyźnie ciągu o proweniencji biblijnej: wiara, nadzieja, miłość. Zaskakujący jest fakt, że w zebranym materiale takie zestawienie słów pojawia się rzadko. Uwagę na to zwraca też A. Bednarek (1989), który podczas swoich badań nie odnalazł ani jednego takiego ciągu.

W grupie kontrolnej istnieje wiele konstrukcji, w których ludzie mówią, że ktoś albo coś daje im nadzieję. W przykładzie (6) tym, co daje nadzieję, jest praca. Pacjenci dostawali nadzieję wyłącznie od ludzi - najczęściej lekarzy. Istotne jest też, że konceptualizator łączy nadzieję ze szczęściem - oba pojęcia należą do językowej rodziny RADOścI. 
(6) Palce mojej ręki każdego dnia zajęte są pracą, która wytycza cel mojego życia, a wszystko to daje mi nadzieję i wręcz pewność... ono jest w moim ręku ... SZCZĘŚCIE.

\section{Nadzieja to istota żywa}

W analizowanym materiale NADZIEJA często jawi się jako ISTOTA ŻYWA - pacjenci przypisują wówczas emocji zachowania ludzkie czy zwierzęce. Jedną z takich podstawowych czynności jest rodzenie się, co zostało zilustrowane w przykładzie (7). Znamienne jest także, że nadzieja współistnieje ze strachem.

(7) W ciągu tego czasu przeżyłam takie spektrum uczuć [...] od czarnego zwątpienia, rozpaczy absolutnej, piekielnej złości poprzez rodzącą się wielką nadzieję przeplataną przez paraliżujący strach, aż do słodkiej radości, że żyję.

Analogicznie - kiedy nadziei zaczyna brakować pacjentom, ci mówią o jej umieraniu (jak w przykładzie (8)). Pojawienie się nadziei na wieść o możliwościach leczenia konceptualizowane jest także jako budzenie się tej emocji:

(8) W czwartek odebrałam wiadomość od Pani dr - mutacji nie ma. Badań nie będzie, nadzieja umarła. Guz w tym czasie urósł dwukrotnie.

W grupie kontrolnej odnaleziono znacznie mniej konstrukcji, z których wyłania się metafora NADZIEJA TO ISTOTA ŻYWA, ale są to konstrukcje podobne.

\section{Nadzieja to ciecz, ciało to pojemnik na uczucia}

U podstaw metafory NADZIEJA TO CIECz leży związany z ciałem schemat wyobrażeniowy POJEMNiKA, którym jest ludzkie ciało (mogą nim też być konkretne organy). Uczucia natomiast zyskują wymiar CIECzy - ta będzie wypetniała, zalewała, przepetniała POJEMNIKI (Johnson 1987; Nowakowska-Kempna 1995, 2000).

W przykładzie (9) nadzieja jawi się jako CIECz, którą konceptualizator może przelewać, czyli dzielić się nią z najbliższymi osobami. Pojemnikiem są serca i umysły - tak pacjenta, jak i jego najbliższych. Wypowiedź ta stanowi ilustrację jednej z podstawowych tez kognitywistów o niepodzielności umysłu i ciała w procesie powstawania emocji (por. np. Nowakowska-Kempna 1995). Nadzieja została pacjentowi przez lekarza zaszczepiona $w$ sercu. Szczepionka zwykle ma postać cieczy, dlatego może ona zostać przelana w serca i umysty innych osób. Wydaje się zatem, że wyłania się z tych słów metafora NADZIEJA TO SZCZEPIONKA. 
(9) Nadzieja, a może nawet pewność możliwości wyleczenia, którą zaszczepiła mi w serce i umysł pani doktor okazała się tak silna, iż udało mi się ją (przynajmniej w części) przelać w serca i umysły moich najbliższych.

Pojemnikiem mogą być także oczy. Odgrywają one szczególną rolę w konceptualizacji emocji - z oczu można wyczytać niemal każde uczucie, co prowadzi do powstania metafory OCZY TO ZWIERCIADŁO DUSZY (ibid.). W przykładzie (10) wzrok pacjenta był pełen nadziei:

(10) Na salę wpadły pielęgniarki i lekarze. Odłączyli mnie od drenażu, a ja tylko pytającym i pełnym nadziei wzrokiem skakałam to z pielęgniarki to na lekarza. Co teraz?

W grupie kontrolnej odnaleziono zdecydowanie mniej konstrukcji językowych, z których wyłaniałoby się odwzorowanie NADZIEJA TO CIECz. Ludzie zdrowi, nawet jeśli konceptualizują $w$ ten sposób tę emocję, to czynią to $w$ zdecydowanie mniej różnorodnych konstrukcjach, sięgają zwykle po zwrot być pełnym nadziei.

\section{Nadzieja to ogień}

Ludzie, mówiąc o nadziei, używają często konstrukcji czasownikowych, które wywołują jednoznaczne asocjacje z OGNIEM. Możliwości rozpalania nadziei zwykle nie ma sam konceptualizator - dysponuje nią osoba postronna. Pacjentka, u której leczenie nie przynosi pożądanych efektów, wskazuje na lekarzy, którzy nie rozpalają w niej takiego uczucia:

(11) Leczę się już dwa lata i do tej pory ani razu nie usłyszałam dobrych wieści, nie spodziewam się więc, że coś się zmieni, a moi lekarze również nie rozpalają we mnie nadziei.

W przykładzie (12) nadzieja jawi się także jako iskra, którą można wykrzesać:

(12) Choroba nowotworowa to nowe i z pewnością trudne doświadczenie, ale traktuje je jako niezwykle cenną lekcję: [...] lekcję z krzesania iskier nadziei.

Uczucie to, tak jak ogIEŃ, można też zgasić:

(13) Żyję z niepokojem o to, co pokaże kolejna tomografia, ale nie gasi to we mnie nadziei. 
Ludzie zdrowi zdecydowanie rzadziej konceptualizują tę emocję jako ogIEŃ, czynią to jednak podobnie jak ludzie chorzy. Również mówią o iskrze nadziei albo o tym, że nadzieja tli się w sercu.

\section{Nadzieja to przedmiot kruchy}

U podstaw metafory NADZIEJA TO PRZEDMIOT KRUCHY leży schemat wyobrażeniowy PRzEDMIOTU. Nadzieja jawi się jako przedmiot delikatny, który z łatwością można rozbić - w przykładzie (14) nadzieja zostaje rozbita mina lekarki na drobne kawałeczki:

(14) No i przyszedł dzień ostatni! Żyję! Za chwilę wychodzę, czekam jeszcze na swoją lekarkę [...]. Wchodzi lekarka, jej mina rozbija moją nadzieję na drobne kawałeczki. - „Pani Marzeno, nie jest dobrze. Nie ma żadnej poprawy [...]”.

Ludzie zdrowi zdecydowanie rzadziej konceptualizują NADZIEJĘ jako PRZEDMIOT KRUCHY, jednak czynią to podobnie jak ludzie chorzy.

\section{Nadzieja to ziarno}

W analizowanym materiale odnaleziono przykład metafory niekonwencjonalnej, a mianowicie: NADZIEJA TO ZIARNO. W powstawaniu tego typu metafor istotną rolę odgrywają wpływy kulturowe oraz procesy poznawcze, a ich interpretacja jest ściśle uzależniona od kontekstu społecznego (El Refaie 2009: 181-182).

Ten typ metafory odnaleziono wyłącznie $\mathrm{w}$ wypowiedziach ludzi chorych. Za szczególnie interesujący uznano przykład (15), w którym obecny jest złożony scenariusz metaforyczny. Pacjent mówi o ziarenku nadziei (zamiast ziarnie), uwypuklając w ten sposób niewielką ilość tego uczucia. Ziarenko nadziei zostaje zaszyte przez ortopedę. W prototypowej sytuacji ziarno się zasiewa, nigdy zaszywa. Zaszywanie jest natomiast czynnością typową dla ortopedy - wydaje się, że metafora ta powstała na skutek torowania kontekstowego. Okoliczności, w jakich znalazł się konceptualizator (pobyt w szpitalu i przejście operacji), wpłynęły w specyficzny sposób na konceptualizację tej emocji.

(15) Wyobraź to sobie. Mój ortopeda zaszył we mnie ziarenko nadziei. Doczepił mi skrzydła. 


\section{Nadzieja to matka}

NADZIEJA TO MATKA to bardziej szczegółowa realizacja metafory NADZIEJA TO OsoBA, która z kolei jest specyfikacją odwzorowania NADZIEJA TO ISTOTA żYwA. Ten typ metafory odnaleziono zarówno w grupie podstawowej, jak i kontrolnej - tak ludzie chorzy, jak i zdrowi, mówiąc o nadziei jak o matce, sięgają po frazeologizm nadzieja matka głupich. W przykładzie (16) pacjent, używając zwrotu nadzieja matka głupich, daje wyraz swojemu rozczarowaniu.

(16) Niewielka przekąska przed obiadem z nadzieją, że będzie dobry. Niestety nadzieja matką głupich.

\section{Nadzieja to zbiornik wodny}

Jedynie w grupie kontrolnej odnaleziono konstrukcje językowe, w których NADzIEJA jawi się jako zBIORNIK WODNy. Uczucie to opisywane jest jako głębokie, można przypuszczać, że w tych przykładach nadzieja jest konceptualizowana jako uczucie w dużej ILOści. Bardziej skomplikowany obraz NADzIEI wyłania się z przykładu (17). Życie wydaje się niecką, którą wypełniają uczucia (między innymi nadzieja), a konceptualizator się w nich zatapia.

(17) Zatapiamy się w życiu pełnym miłości, strachu, upokorzeń, nadziei, rozczarowań i namiętności.

\section{Wnioski}

W badanym materiale ludzie chorzy mówią o nadziei nieco częściej niż ludzie zdrowi i czynią to, używając bardziej skomplikowanych konstrukcji. Z analizy licznych konstrukcji językowych, z których wyłania się metafora NADZIEJA TO RZECZ CENNA, wynika, że emocja ta jest uniwersalnym doświadczeniem, ważnym w życiu wszystkich ludzi, co znajduje potwierdzenie w niemal każdym ujęciu psychologicznym. Charakterystyczne jest, że ludzie chorzy, konceptualizując to uczucie, przedstawiają siebie - podmiot emocji - jako biernych, co jest rzadkością w grupie kontrolnej. Pacjenci, w przeciwieństwie do osób zdrowych, mówią zwykle o niewielkiej ilości nadziei, wyjątkiem są jedynie kolokacje, z których wyłania się metafora NADZIEJA TO CIECz. Szczególnie interesująca okazała się wypowiedź realizująca metaforę NADZIEJA TO ZIARNO - stanowi ona przykład udziału kontekstu w powstawaniu metafor. Przypuszczalnie to doświadczenia szpitalne pełnią funkcję czynników kontekstowych, które utorowały drogę do powstania tego odwzorowania. 
Przebadany materiał jest niewątpliwie ograniczony, wobec czego przedstawione wyniki mają charakter sondażowy. Korzystne wydaje się prowadzenie dalszych badań, zwłaszcza uwzględniających dane językowe pochodzące z innych źródeł (na przykład z badań ankietowych).

\section{Literatura}

BARtmiński J., 1989, Projekt i założenia ogólne słownika aksjologicznego, [w:] J. Puzynina, J. Bartmiński (red.), Język a kultura, t. 2: Zagadnienia leksykalne i aksjologiczne, Wrocław, s. 293-312.

Bednarek A., 1989, O nadziei. Próba definicji semantycznej, [w:] J. Puzynina, J. Bartmiński (red.), Język a kultura, t. 2: Zagadnienia leksykalne i aksjologiczne, Wrocław, s. 327-354.

Duszak A., Pawlak N. (red.), 2003, Anatomia gniewu. Emocje negatywne w językach i kulturach świata, Warszawa.

El Refaie E., 2009, Metaphor in Political Cartoons: Exploring Audience Responses, [w:] Ch.J. Forceville, E. Urios-Aparisi (red.), Multimodal Metaphor, Berlin - New York, s. $173-196$.

Erikson E.H., 1985, The Life Cycle Completed: A Review, New York.

Erikson E.H., 2002, Dopetniony cykl życia, Poznań.

GawdA B., 2018, Struktura pojęcia „nadzieja” i jego zróżnicowanie, „Annales Universitatis Mariae Curie-Skłodowska. Sectio J: Paedagogia - Psychologia” t. 31, nr 4, s. 65-81, https:// doi.org/10.17951/j.2018.31.4.65-81.

JęDRZEJKO E., 2000, O językowych wykładnikach pojęcia wSTYD w różnych koncepcjach opisu, [w:] I. Nowakowska-Kempna, A. Dąbrowska, J. Anusiewicz (red.), Język a kultura, t. 14: Uczucia w języku i tekście, Wrocław, s. 60-75.

Johnson M., 1987, The Body in the Mind: The Bodily Basis of Meaning, Imagination, and Reason, Chicago, https://doi.org/10.7208/chicago/9780226177847.001.0001.

KARAś H., 2003, Językowa konceptualizacja uczuć z grupy sTRACHU na podstawie konstrukcji werbo-nominalnych, „Poradnik Językowy” nr 4, s. 27-35.

KlATKIEWiCz A., 2010, Kobieta i mężczyzna w procesie pomocy psychologicznej i psychoterapeutycznej - czy płeć ma znaczenie?, „Nowiny Lekarskie” 79, nr 1, s. 39-46.

Kövecses Z., 2000, Metaphor and Emotion, Cambridge.

Kövecses Z., 2002, Metaphor: A Practical Introduction, Oxford.

Kövecses Z., 2017, Conceptual Metaphor Theory: Some New Proposals, „LaMiCuS” 1, s. $16-32$.

KozIElecki J., 2006, Psychologia nadziei, Warszawa.

Kruś S., Skrzy pek-Fakhoury E. (red.), 2007, Patomorfologia kliniczna, wyd. 3 uaktual. i rozsz., Warszawa.

Lakoff G., Johnson M., 1980/2010, Metaphors We Live by, Chicago.

Lazarus R.S., 1999, Hope: An Emotion and Vital Coping Resource Against Despair, „Social Research" 66, nr 2, s. 653-678.

MiкоŁajCzuк A., 1999, Gniew we współczesnym języku polskim. Analiza semantyczna, Warszawa.

Miкоєаjczuк A., 2009, Obraz radości we współczesnej polszczyźnie, Warszawa. 
MikoŁajCzuk A., 2013, O radości w ujęciu lingwistycznym. Z problemów semantycznych badań porównawczych, „Etnolingwistyka. Problemy Języka i Kultury” 5, s. 219-238.

Nowakowska-Kempna I., 1995, Konceptualizacja uczuć w języku polskim. Prologomena, Warszawa.

Nowakowska-Kempna I., 2000, Konceptualizacja uczuć w języku polskim. Część II. Data, Warszawa.

PopowiCz J., 2018, RADOść we współczesnym języku hiszpańskim i polskim. Kognitywna analiza semantyczna wybranych leksemów, Kraków.

Tомсzак K., 1994, Frazeologizmy nazywające strach w języku polskim, „Poradnik Językowy" nr 9, s. 26-33.

SNyDER R.Ch., 2002, Hope Theory: Rainbows in the Mind, „Psychological Inquiry” 13, nr 4, s. 249-275, https://doi.org/10.1207/S15327965PLI1304_01.

Sовотка P., 2010, Norwidowska koncepcja nadziei, „Linguistica Copernicana” 4, nr 2, s. 6999, https://doi.org/10.12775/LinCop.2010.020.

WierzbickA A., 1971, Kocha, lubi, szanuje. Medytacje semantyczne, Warszawa.

WierzBickA A., 1999, Emocje. Język i „skrypty kulturowe”, [w:] eadem, Język - Umyst - Kultura. Wybór prac, red. J. Bartmiński, Warszawa, s. 163-192.

\section{Conceptualization of Hope in Conceptual Metaphors in the Statements of Patients with Malignant Tumor and Healthy People \\ Abstract}

The article presents the results of analyses of language structures obtained from blog texts, divided into two parts: research group and control group. The analyses aimed at checking which metaphors are used to conceptualize hope among people with cancer and healthy people, and to identify differences in the conceptualization of this feeling. The difference is in the attitude of the conceptualising people: patients describe themselves more often as passive participants in events, and they usually borrow hope from others, while healthy people are more active. The issue of the influence of individual contextual factors on the formation of metaphors is also very interesting. 